\title{
Thermodynamics of high-temperature superconducting materials
}

\author{
Gennadij F. Voronin \\ Chemistry Department, Moscow State University, 119899 Moscow, USSR
}

\begin{abstract}
In this paper, the problem of thermodynamic stability of new high-temperature superconductors is discussed. This problem can only be solved with the help of thermodynamic investigations, including experimental studies of thermodynamic properties and calculations of equilibria, which require a considerable amount of thermodynamic data. Now such a set of data is only available for the phases in the $\mathrm{Y}-\mathrm{Ba}-\mathrm{Cu}-\mathrm{O}$ system. In this system, phase equilibria have been calculated and the stability regions of the superconducting compounds and solutions established. It has been found that the 123, 247 and 124 superconductors are thermodynamically unstable under application conditions. The methods of theoretical and experimental investigations and available thermodynamic properties of phases are briefly reviewed.
\end{abstract}

\section{INTRODUCTION}

There are two distinct areas of study in the field of the thermodynamics of superconductors. The first, traditionally developed by physicists, is based on ideas concerning the phenomenon of superconductivity as a phase transition in a system of bosons that are particles with an integer value of the spin quantum number. Of course the mechanism of the formation of the bosons, such as the Cooper pairs of electrons or holes in a crystal, cannot be determined within the framework of the thermodynamic approach. However, the theory and methods of the thermodynamics of phase transitions are completely applicable to the analysis of the conditions for the condensation of the Bose-liquid. They permit the derivation of many useful relationships between the macroscopic properties of superconductors. They also allow one to test the physical prerequisites upon which the microscopic models of superconductivity are based.

In the second field of thermodynamic investigations, the specific physical properties of superconductors are not used in an explicit form at all. The methods of thermodynamics are applied to them as to any other materials to predict the phase composition and chemical stability under various conditions such as interactions with the atmosphere and with other materials, on heating, and under the action of an elevated pressure, mechanical stresses, and external force fields. The final goal is the selection of the optimum conditions for the synthesis of a material and use its with the minimum consumption of resources and time. Only such a chemical direction of thermodynamic researches is considered below.

It is possible to develop the thermodynamic models of processes only when a sufficient amount of information on the properties of the substances of interest is available. Usually such a minimum set of data that is sufficient for the calculation of equilibria is formed by the values of the Gibbs energies of the main phases in the system as functions of temperature, pressure, and chemical composition. With respect to thermodynamic investigations, the new high-temperature superconductors (HTSC) are complicated materials. They exist in multicomponent systems with many phases including nonstoichiometric compounds and solutions. Most of the oxide HTSC are either directly the members of the homologous series of compounds $\mathrm{Y}_{2} \mathrm{Ba}_{4} \mathrm{Cu}_{5+n} \mathrm{O}_{13+n}, \mathrm{Bi}_{2} \mathrm{Sr}_{2} \mathrm{Ca}_{n-1} \mathrm{Cu}_{n} \mathrm{O}_{2 n+4}$, $\mathrm{TIBa}_{2} \mathrm{Ca}_{n-1} \mathrm{Cu}_{n} \mathrm{O}_{2 n+3}, \quad \mathrm{Tl}_{2} \mathrm{Ba}_{2} \mathrm{Ca}_{n-1} \mathrm{Cu}_{n} \mathrm{O}_{2 n+4}(\mathrm{n}=1,2, \ldots)$ or derivatives obtained by the 
substitution of one cation for another. For instance, the superconductors $\mathrm{YBa}_{2} \mathrm{Cu}_{3} \mathrm{O}_{6+z}$, $\mathrm{Y}_{2} \mathrm{Ba}_{4} \mathrm{Cu}_{7} \mathrm{O}_{14+\mathrm{z}}$ and $\mathrm{YBa}_{2} \mathrm{Cu}_{4} \mathrm{O}_{8}(0 \leq \mathrm{Z} \leq 1)$ exist in the most simple quaternary $\mathrm{Y}-\mathrm{Ba}-\mathrm{Cu}-\mathrm{O}$ system (these formulae are often abbreviated as 123,247 and 124 respectively). However, to describe the behavior of these HTSC at equilibrium, the Gibbs energies are required not only for those phases but for all the others in this system that can be in equilibrium with superconductors: $\mathrm{Y}_{2} \mathrm{O}_{3}, \mathrm{CuO}, \mathrm{Cu}_{2} \mathrm{O}, \mathrm{BaO}, \mathrm{BaO}_{2}, \mathrm{Y}_{2} \mathrm{BaO}_{4}, \mathrm{Y}_{4} \mathrm{Ba}_{3} \mathrm{O}_{9}, \mathrm{Y}_{2} \mathrm{Ba}_{2} \mathrm{O}_{5}$, $\mathrm{Y}_{2} \mathrm{Ba}_{4} \mathrm{O}_{7}, \mathrm{Y}_{2} \mathrm{Cu}_{2} \mathrm{O}_{5}, \mathrm{YCuO}_{2}, \mathrm{BaCuO}_{2}, \mathrm{BaCu}_{2} \mathrm{O}_{2}, \mathrm{Ba}_{2} \mathrm{CuO}_{3}, \mathrm{Ba}_{2} \mathrm{Cu}_{3} \mathrm{O}_{5}, \mathrm{Ba}_{3} \mathrm{Cu}_{5} \mathrm{O}_{8}, \mathrm{Y}_{2} \mathrm{BaCuO}_{5}$, $\mathrm{YBa}_{2} \mathrm{Cu}_{2} \mathrm{O}_{6}, \mathrm{YBa}_{4} \mathrm{Cu}_{3} \mathrm{O}_{8.5}, \mathrm{YBa}_{2} \mathrm{Cu}_{2} \mathrm{O}_{8.5}, \mathrm{Y}_{2} \mathrm{Ba}_{9} \mathrm{Cu}_{6} \mathrm{O}_{18}$. In fact, many of these phases are nonstoichiometric with respect to oxygen. To describe high-temperature processes, such as the growth of HTSC crystals from a melt, it is also necessary to know the properties of the quaternary $\mathrm{Y}_{x} \mathrm{BaCu}_{\mathrm{z}} \mathrm{O}_{(1-x-y-z)}$ liquid solution as functions of temperature and composition.

For this reason, the thermodynamic investigations of HTSC are only at an early stage. The set of data that are necessary for the calculation of equilibria and stability region of superconductors currently is only available for the solid phases in the $\mathrm{Y}-\mathrm{Ba}-\mathrm{Cu}-\mathrm{O}$ system, and there are a few fragmentary data for the other more complicated systems with HTSC.

\section{SUPERCONDUCTING TRANSITION}

Taking into account the general thermodynamic conditions for equilibrium between normal and superconducting phases and considering the latter as a perfect diamagnetic, it is possible to show that the phase transition into the superconducting state will be first-order if it occurs in an external magnetic field and second order if there is no such a field. In the latter case, the temperature $\left(T_{c}\right)$ of the transition of a substance from the normal $(n)$ into the superconducting $(s)$ state is given by the well-known relation

$$
T_{c}=4 \pi\left(c_{p}^{(s)}-c_{p}^{(n)}\right) /\left[V\left(\partial \mathscr{H}_{c} / \partial T\right)_{p}^{2}\right],
$$

where $c_{p}$ is the heat capacity of the corresponding phase, $V$ is the volume of the substance, and $\left(\partial \mathscr{H}_{c} / \partial T\right)_{p}$ is the slope of the curve representing the temperature dependence of the critical magnetic field strength. Another example is given by the simple and important relation that describes the influence of the pressure $(P)$ on the temperature of the superconducting transition:

$$
\mathrm{d} \ln T_{c} / \mathrm{d} P=V\left(\alpha^{(s)}-\alpha^{(n)}\right) /\left(c_{p}^{(s)}-c_{p}^{(n)}\right),
$$

where $\alpha=(\partial \ln V / \partial T)_{p}$ is the coefficient of volume expansion. The derivative in (2) is positive for the investigated HTSC. This effect can be used to increase $T_{c}$ by several degrees due to elastic strains in the multi-layer structures obtained by a special technology. It is well known that this idea led to the substitution of $Y$ for $L a$ in the $(\mathrm{La}, \mathrm{Ba})_{2} \mathrm{CuO}_{4}$ ceramics and finally the discovery of a new superconductor.

However, attempts to apply these expressions to new superconducting materials may prove unsuccessful because of the nonfulfillment of several initial prerequisites. Thus, available experience shows that superconducting ceramic is not obtained over the whole volume of a sample as a perfect diamagnetic. It has not one but two different curves for the temperature dependence of the critical field, $\mathscr{H}_{c 1}(T), \mathscr{H}_{c 2}(T)$. The thermodynamic value, $\mathscr{H}_{c}$, in such superconductors is usually defined as some kind of mean of $\mathscr{H}_{c 1}(T)$ and $\mathscr{H}_{c 2}(T)$, for example, as a geometric mean. Then, equations (1),(2) as well as all the other relations for the superconducting transition were obtained under the condition of identical chemical compositions of the coexisting phases. With appearance of substances having high values of $T_{c}$, a relationship taking into account the existence of the chemical equilibrium in the phases may prove useful. For a two-component system with a composition including $x$ molar fraction of the component, one can obtain instead of $(1)$ :

$$
T_{c}=4 \pi\left(c_{p}^{(s)}-c_{p}^{(n)}\right)\left(\partial T_{c} / \partial x\right)_{T, p}^{2} /\left[V\left(\partial \mathscr{H}_{c} / \partial x\right)_{T, p}^{2}\right] .
$$


Commonly, the equations for superconducting transition at chemical equilibria can be complicated owing to the complex nature of the functions $\mathscr{H}_{c}(T, P, x)$.

\section{SYNOPSIS OF EXPERIMENTAL METHODS}

All the new HTSC are the open systems with respect to atmospheric oxygen. They 'breathe' oxygen and can exist as equilibrium specimens only at somewhat large values of oxygen chemical potential or partial pressure. For this reason, many of traditional experimental methods are not applicable for thermodynamic study of these substances. Thus, this is the case for the methods based on vaporization or effusion of species into vacuum, such as high-temperature mass-spectrometry. Calorimetry faces the similar problems since quenched and obviously nonequilibrium specimens are involved or it is necessary to provide for conservation of oxygen content in the specimen. As a rule, the results obtained between these extreme opportunities cannot be strictly interpreted. As seen from Fig. 1, the specific heats of the 123 phase can differ markedly if they are measured under different conditions.

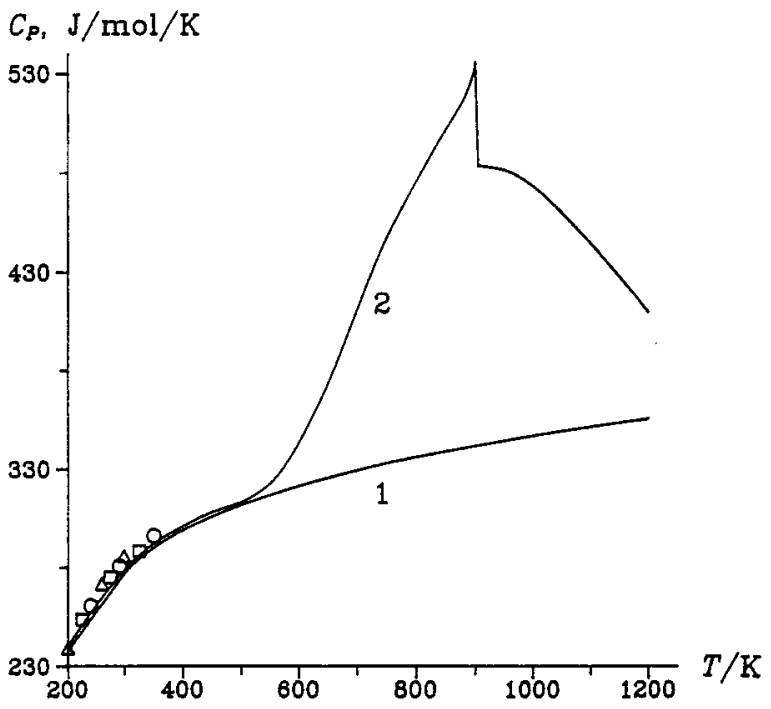

Fig. 1. Specific heat of $\mathrm{YBa}_{2} \mathrm{Cu}_{3} \mathrm{O}_{6+2}$ as a function of temperature at a fixed composition, $z=0.9$, (line 1) and at 0.21 atm of equilibrium oxygen pressure, (line 2). The points represent the data from refs. 1-3. The lines are calculated according to the equations $(7)-(11)$.

Most of the experimental thermodynamic studies of HTSC materials concerned the sintered ceramic specimens of the 123 phase in the $\mathrm{Y}-\mathrm{Ba}-\mathrm{Cu}-\mathrm{O}$ system. The gas phase equilibria were most often used for these purposes. The specimen was annealed in controlled atmosphere, quenched and its phase and chemical composition determined. X-ray diffraction was generally used for phase identification and chemical analyses - for determination of oxygen content. The partial thermodynamic properties of oxygen in the 123 solid solution and the equilibrium conditions of invariant reactions in a heterogeneous mixture of compounds were determined in this way. An electrochemical oxygen pump was often used to create the appropriate gas atmosphere. To change the composition of a sample precisely, the coulometric titration and thermogravimetry were used with success in several works (refs. 4, 5). Most of the experimental studies have been recently reviewed (refs. 6, 7). The integral thermodynamic properties of HTSC, Gibbs energy, enthalpy and entropy of individual compounds and solutions however, have not been extensively studied. They were measured in a few studies by an electromotive force method (emf) over the range of about 950 to $1150 \mathrm{~K}$. For example, in a series of papers (refs. 8-11), the following electrochemical cells were assembled for this purpose:

(Pt) $\mathrm{O}_{2}\left|\mathrm{BaCuO}_{2}, \mathrm{CuO}, \mathrm{BaF}_{2}\left\|\mathrm{BaF}_{2}\right\| \mathrm{CaO}, \mathrm{CaF}_{2}\right| \mathrm{O}_{2}(\mathrm{Pt})$

(Pt) $\mathrm{O}_{2}\left|\mathrm{Y}_{2} \mathrm{O}_{3}, \mathrm{YOF}\left\|\mathrm{CaF}_{2}\right\| \mathrm{Y}_{2} \mathrm{Cu}_{2} \mathrm{O}_{5}, \mathrm{CuO}, \mathrm{YOF}\right| \mathrm{O}_{2}(\mathrm{Pt})$

(Pt) $\mathrm{O}_{2}\left|\mathrm{Y}_{2} \mathrm{BaCuO}_{5}, \mathrm{Y}_{2} \mathrm{Cu}_{2} \mathrm{O}_{5}, \mathrm{CuO}, \mathrm{BaF}_{2}\left\|\mathrm{BaF}_{2}\right\| \mathrm{CaO}, \mathrm{CaF}_{2}\right| \mathrm{O}_{2}(\mathrm{Pt})$

(Pt) $\mathrm{O}_{2}\left|\mathrm{Y}_{2} \mathrm{BaCuO}_{5}, \mathrm{Y}_{2} \mathrm{Cu}_{2} \mathrm{O}_{5}, \mathrm{Y}_{2} \mathrm{O}_{3}, \mathrm{BaF}_{2}\left\|\mathrm{BaF}_{2}\right\| \mathrm{CaO}, \mathrm{CaF}_{2}\right| \mathrm{O}_{2}(\mathrm{Pt})$ 
(Pt) $\mathrm{O}_{2}\left|\mathrm{BaO}, \mathrm{BaF}_{2}\left\|\mathrm{BaF}_{2}\right\| \mathrm{CaO}, \mathrm{CaF}_{2}\right| \mathrm{O}_{2}(\mathrm{Pt})$

(Pt) $\mathrm{O}_{2}\left|\mathrm{BaCu}_{2} \mathrm{O}_{2}, \mathrm{Cu}_{2} \mathrm{O}, \mathrm{BaF}_{2}\left\|\mathrm{BaF}_{2}\right\| \mathrm{CaO}, \mathrm{CaF}_{2}\right| \mathrm{O}_{2}(\mathrm{Pt})$

(Pt) $\mathrm{O}_{2} \mid \mathrm{YBa}_{2} \mathrm{Cu}_{3} \mathrm{O}_{6+z}, \mathrm{Y}_{2} \mathrm{BaCuO}_{5}, \mathrm{BaCuO}_{2}, \mathrm{BaF}_{2} \| \mathrm{BaF}_{2}$

$$
\| \mathrm{YBa}_{2} \mathrm{Cu}_{3} \mathrm{O}_{6+2}, \mathrm{Y}_{2} \mathrm{BaCuO}_{5}, \mathrm{CuO}, \mathrm{BaF}_{2} \mid \mathrm{O}_{2}(\mathrm{Pt})
$$

(Pt) $\mathrm{O}_{2}\left|\mathrm{BaCuO}_{2}, \mathrm{CuO}, \mathrm{BaF}_{2}\left\|\mathrm{BaF}_{2}\right\| \mathrm{YBa}_{2} \mathrm{Cu}_{3} \mathrm{O}_{6+\mathrm{z}}, \mathrm{Y}_{2} \mathrm{BaCuO}_{5}, \mathrm{CuO}, \mathrm{BaF}_{2}\right| \mathrm{O}_{2}(\mathrm{Pt})$

The electromotive force was measured on each cell at several tens of temperatures. The measurements on cells (I), (VI), and (VIII) were made at various oxygen pressures ranging from 0.001 to 1 atm. In the other cases, the oxygen pressure was equal to 1 atm. This study makes it possible to obtain thermodynamic functions of almost all the major phases in the vicinity of 123 via several independent ways combining data for different galvanic cells. For example, the Gibbs energy change a reaction $\mathrm{Y}_{2} \mathrm{O}_{3}+2 \mathrm{CuO}=\mathrm{Y}_{2} \mathrm{Cu}_{2} \mathrm{O}_{5}$ is the following:

$$
\Delta_{r} G^{O x}\left(\mathrm{Y}_{2} \mathrm{Cu}_{2} \mathrm{O}_{5}\right)=-2 \mathscr{F} \mathscr{E}(\mathrm{II})=4 \mathscr{F}(\mathscr{E}(\mathrm{IV})-\mathscr{E}(\mathrm{III})) \text {, }
$$

where $\mathscr{E}$ is the electromotive force, $\mathscr{F}$ is the Faraday constant, indexes (f) and (ox) here and below denote the formation of a compound from oxides and oxygen. The same investigations of the $\mathrm{Y}-\mathrm{Ba}-\mathrm{Cu}-\mathrm{O}$ system were carried out in air and on the cell employing calcium fluoride as electrolyte (ref, 12).

A thermodynamic method for the determination of oxygen nonstoichiometry in HTSC is of particular interest (refs. 9, 15). It allows one to find the oxygen content in nonstoichiometric compounds or solutions during the measurements of their thermodynamic properties. This method is based on the dependence of the emf of an electrochemical cell on the oxygen pressure over the cell when oxygen takes part in a net electrochemical reaction. A formula for the calculation of nonstoichiometric index $(z)$ is

$$
\mathrm{z}= \pm\left(\partial \Delta_{r} G / \partial \ln P\left(\mathrm{O}_{2}\right)\right)_{T} / R T,
$$

where $\Delta_{r} G$ is the Gibbs energy of the net cell reaction. Figure 2 shows the application of this method for the $\mathrm{Sr}_{14} \mathrm{Cu}_{24} \mathrm{O}_{38+z}$ compound at $1150 \mathrm{~K}$ based on two different cells. The first cell is $(\mathrm{Pt}) \mathrm{O}_{2}\left|\mathrm{SrO}, \mathrm{SrF}_{2}\left\|\mathrm{SrF}_{2}\right\| \mathrm{Sr}_{14} \mathrm{Cu}_{24} \mathrm{O}_{38+\mathrm{z}}, \mathrm{CuO}, \mathrm{SrF}_{2}\right| \mathrm{O}_{2}(\mathrm{Pt})$, and its net reaction is $14 \mathrm{SrO}+24 \mathrm{CuO}+(\mathrm{z} / 2) \mathrm{O}_{2}=\mathrm{Sr}_{14} \mathrm{Cu}_{24} \mathrm{O}_{38+z}$; the second one is $(\mathrm{Pt}) \mathrm{O}_{2} \mid \mathrm{SrO}, \mathrm{SrF}_{2} \| \mathrm{SrF}_{2}$ $\| \mathrm{SrCuO}_{2}, \mathrm{Sr}_{14} \mathrm{Cu}_{24} \mathrm{O}_{38+\mathrm{z}}, \mathrm{SrF}_{2} \mathrm{O}_{2}(\mathrm{Pt})$ with the net reaction $\mathrm{Sr}_{14} \mathrm{Cu}_{24} \mathrm{O}_{38+\mathrm{z}}+10 \mathrm{SrO}=24 \mathrm{SrCuO}_{2}+$ $(\mathrm{z} / 2) \mathrm{O}_{2}$. As seen in Fig. 2, at oxygen pressure from 0.1 to $1 \mathrm{~atm}$, the composition of the phase under consideration remains constant, so that it has a formula $\mathrm{Sr}_{14} \mathrm{Cu}_{24} \mathrm{O}_{41}$.

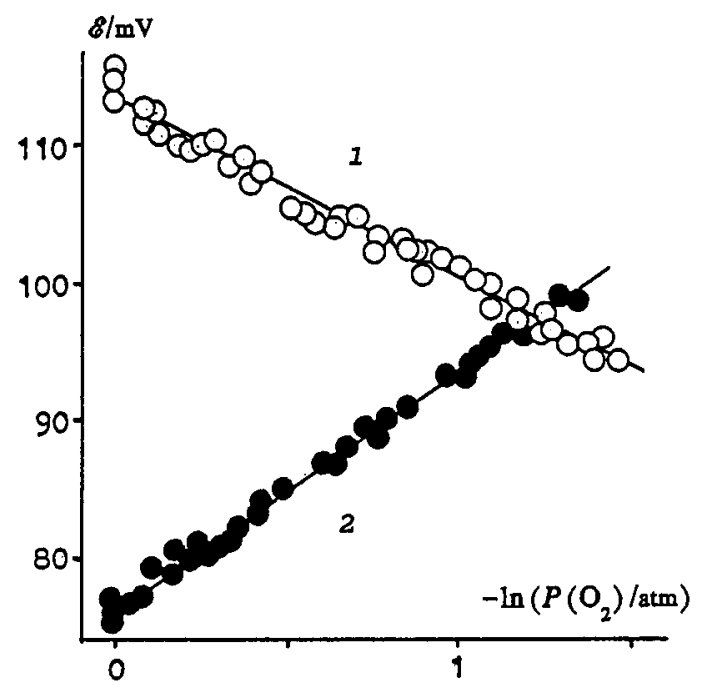

Fig. 2. Oxygen content in $\mathrm{Sr}_{14} \mathrm{Cu}_{24} \mathrm{O}_{41}$ at $1150 \mathrm{~K}$ obtained by emf measurements. For cell $1, \mathrm{z}=28 \mathscr{F}\left(\partial \mathscr{E} / \partial P\left(\mathrm{O}_{2}\right)\right) / R T=3.03 \pm 0.15$, for cell $2, \mathrm{z}=-20 \mathscr{F}\left(\partial \mathscr{E} / \partial P\left(\mathrm{O}_{2}\right)\right) / R T=3.06 \pm 0.08$. 
Different calorimetric investigations of heat capacities of the HTSC from very low to room temperatures are in reasonable agreement as, in particular, Fig. 1 shows (refs. 1-3). Yet the data obtained by solution calorimetry gave too large discrepancies that were not peculiar for this method (e.g., cf. ref. 13 and ref. 14). Evidently, this was because of the quality of the specimens studied. Unfortunately, many erroneous results that have not withstood rechecking have been also obtained by other methods. Frequently, poor reproducibility results from incomplete conversion of the initial substances during the synthesis or the pronounced influence of the surrounding gaseous medium on the composition and properties of the specimen and its interactions with water vapor, carbon dioxide, and the materials of crucibles and substrates.

\section{THERMODYNAMIC DATA}

Thus, the thermodynamic properties of the HTSC have been little studied. Even for the well investigated $\mathrm{Y}-\mathrm{Ba}-\mathrm{Cu}-\mathrm{O}$ system, the thermodynamic functions of the 124 and 247 superconductors have not been studied experimentally yet, the experimental data for the 123 phase are still incomplete and there are no data for the liquids. Moreover, the available data often disagree and consequently cannot be used directly for the calculation of phase equilibria and solution of the practical problems related to determination of the synthesis conditions and stability of the superconductors. In such a case, the extraction of thermodynamic information from experimental data on phase equilibria is of particular importance as the semi-empirical estimate of thermodynamic properties. For example, the entropies of phases in the superconducting systems at $298 \mathrm{~K}$ can be estimated by adding the following atomic contributions: $\mathrm{Y}(51.5), \mathrm{Ba}(63.2), \mathrm{Cu}(41.0)$, $\mathrm{La}(60.7)$, Sr (48.5), O (3.2) in $\mathrm{J} / \mathrm{mol} / \mathrm{K}$ (ref. 16). Such an estimate gives for the $\mathrm{La}_{2} \mathrm{CuO}_{4}$ compound $\mathrm{S}_{298.2}=2(60.7)+41+4(3.2)=175.2$, as compared with the experimental value $178.2 \mathrm{~J} / \mathrm{mol} / \mathrm{K}$ (ref. 17).

In the $\mathrm{Y}-\mathrm{Ba}-\mathrm{Cu}-\mathrm{O}$ system a self-consistent set of thermodynamic functions was derived from available experimental data and phenomenological models of phases in this system (refs. 11,18$)$. These models were developed for all the superconducting phases and for the $\mathrm{Ba}_{2} \mathrm{Cu}_{3} \mathrm{O}_{5+\mathrm{y}}$ solid solutions. The parameters of the model for the 123 phase were determined with the help of more than 600 experimental data points including different thermodynamic and structural measurements. The thermodynamic functions of formation of the 123 phase from $\mathrm{Y}_{2} \mathrm{O}_{3}, \mathrm{BaO}, \mathrm{CuO}$ and oxygen at temperatures above $200 \mathrm{~K}$ are the following:

$$
\begin{aligned}
& \Delta_{f} G^{o x}\left(\mathrm{YBa}_{2} \mathrm{Cu}_{3} \mathrm{O}_{6+\mathrm{z}}\right)=\Delta_{f} H^{o x}-T \Delta_{f} S^{o x}, \\
& \Delta_{f} H^{o x} / R=A_{1}+A_{2} \mathrm{z}+\mathrm{z}(1-\mathrm{z}) a_{1}^{\mathrm{h}}+\left(c^{2}-x^{2}\right) b_{1}^{\mathrm{h}}-\Delta_{r} H^{\circ} / R, \\
& \Delta_{f} S^{o x} / R=B_{1}+B_{2} \mathrm{z}+\mathrm{z}(1-\mathrm{z})\left(a_{1}^{\mathrm{s}}+a_{2}^{\mathrm{s}}(1-\mathrm{z})\right)+\left(c^{2}-x^{2}\right) b_{1}^{s}+S_{d}-\Delta_{r} S^{o} / R, \\
& S_{d} / R=-(c+x) \ln (c+x)-(c-x) \ln (c-x)-(1-c+x) \ln (1-c+x) \\
& \quad-(1-c-x) \ln (1-c-x)-\mathrm{z} \ln \mathrm{z}-(1-\mathrm{z}) \ln (1-\mathrm{z}),
\end{aligned}
$$

where $x$ is the order parameter dependent on the oxygen ordering in the 123 phase ( $x=0$ for the tetragonal phase and $x=c$ for the completely ordered orthorhombic phase), $c=$ $\mathrm{z} / 2 ; R=8.314 \mathrm{~J} / \mathrm{mol} / \mathrm{K} ; A_{1}=-13475 \mathrm{~K} ; B_{1}=-2.543 ; A_{2}=-10669.8 \mathrm{~K} ; B_{2}=-10.4058 ; a_{1}^{\mathrm{h}}=$ $886.731 \mathrm{~K} ; a_{1}^{\mathrm{s}}=0.4871 ; a_{2}^{\mathrm{s}}=-1.4204 ; b_{1}^{\mathrm{h}}=1158.53 \mathrm{~K}, b_{1}^{\mathrm{s}}=-3.33514$. The standard functions $\Delta_{r} H^{\circ}$ and $\Delta_{r} S^{\circ}$ correspond to the reaction $\mathrm{Cu}_{2} \mathrm{O} / 2+\mathrm{O}_{2} / 4=\mathrm{CuO}$. The equilibrium values of $x, z$ and $P\left(\mathrm{O}_{2}\right)$ are interrelated by equations

$$
\begin{aligned}
& \operatorname{Tn}((c+x)(1-c+x) /((c-x)(1-c-x)))=2\left(b_{1}^{\mathrm{h}}-T b_{1}^{\mathrm{s}}\right) x \\
& \ln P\left(\mathrm{O}_{2}\right)=\ln \left((c+x)(c-x) \mathrm{z}^{2} /\left((1-c-x)(1-c+x)(1-\mathrm{z})^{2}\right)\right)+ \\
&+2\left[A_{2}-T B_{2}+\left(a_{1}^{h}-T a_{1}^{\mathrm{s}}\right)(1-2 \mathrm{z})-T a_{2}^{\mathrm{s}}(1-\mathrm{z})(1-3 \mathrm{z})+c\left(b_{1}^{\mathrm{h}}-T b_{1}^{\mathrm{s}}\right)\right] / T .
\end{aligned}
$$

Thermodynamic functions of the 247 solid solution are described by the same formulas where the terms $\Delta_{r} H^{\circ}$ and $\Delta_{r} S^{\circ}$ are doubled and the parameters $A_{1}$ and $B_{1}$ are replaced by $A_{1}=-39699 \mathrm{~K}$ and $B_{1}=-15.492$. Unlike the 123 phase, the model for the $\mathrm{Ba}_{2} \mathrm{Cu}_{3} \mathrm{O}_{5+y}$ $(0 \leq y \leq 1)$ solid solution was obtained with the help of only two available experimental studies (refs. 8, 19). The entropies of the end-member compounds of this solution, the 
$\mathrm{Ba}_{2} \mathrm{Cu}_{3} \mathrm{O}_{5}$ and $\mathrm{Ba}_{2} \mathrm{Cu}_{3} \mathrm{O}_{6}$, were estimated at $298 \mathrm{~K}$ as mentioned above. The following description of properties was derived for the temperature range 298-1300 K

$$
\begin{array}{r}
\Delta_{f} G^{a x}\left(\mathrm{Ba}_{2} \mathrm{Cu}_{3} \mathrm{O}_{5+y}, T, P\left(\mathrm{O}_{2}\right)\right) / R=0.99 T-8490 / \mathrm{K}+(11.39 T-12292 / \mathrm{K}) y+ \\
+(11.76 T-13578 / \mathrm{K}) y(1-y)+(y \ln y+(1-y) \ln (1-y)) T, \\
\ln \left(P\left(\mathrm{O}_{2}\right)(1-y)^{2} / y^{2}\right) / 2=(1-2 y)(11.76-13578 / T)+11.39-12292 / T .
\end{array}
$$

This phase has been studied recently. It is possible that the $\mathrm{Ba}_{2} \mathrm{Cu}_{3} \mathrm{O}_{5+y}$ phase was identified with the formula $\mathrm{BaCuO}_{2.35}$ in early work (refs. 8, 11). The thermodynamic functions of the other compounds that have been used for the calculation of equilibria in the $\mathrm{Y}-\mathrm{Ba}-\mathrm{Cu}-\mathrm{O}$ system are summarized in Table 1.

TABLE 1. Standard thermodynamic functions of compounds in the $\mathrm{Y}-\mathrm{Ba}-\mathrm{Cu}-\mathrm{O}$ system at $298 \leq T / \mathrm{K} \leq 1250$.

\begin{tabular}{lccrl}
\hline Phase & $\mathrm{A} / \mathrm{K}$ & $\mathrm{B}$ & $\mathrm{C}$ & \multicolumn{1}{c}{ Source } \\
\hline $\mathrm{CuO}$ & -19118.1 & 17.1162 & 1.0139 & ref. 20 \\
$\mathrm{Cu} \mathrm{O}_{2}$ & -20772.0 & 12.7751 & 0.5930 & ref. 20 \\
$\mathrm{BaO}$ & -65361.4 & 4.0115 & -1.1405 & ref. 20 \\
$\mathrm{Y}_{2} \mathrm{O}_{3}$ & -231435.6 & 46.1430 & 1.7960 & refs. 21,22 \\
$\mathrm{BaCuO}_{2}$ & -89148.5 & 20.8667 & -0.2586 & ref. 8 \\
$\mathrm{BaCu}_{2} \mathrm{O}_{2}$ & -91675.6 & 17.2576 & -0.5955 & ref. 9 \\
$\mathrm{Y}_{2} \mathrm{Cu}_{2} \mathrm{O}_{5}$ & -268318.7 & 79.2704 & 3.9798 & ref. 10 \\
$\mathrm{YCuO}_{2}$ & -126058.7 & 29.1910 & 1.2065 & refs. 23,10 \\
$\mathrm{Y}_{2} \mathrm{BaCuO}_{5}$ & -321716.6 & 58.1347 & 0.2624 & refs. 10,11 \\
$\mathrm{YBa}_{4} \mathrm{Cu}_{3} \mathrm{O}_{8.5}$ & -452402.4 & 88.8101 & -1.1513 & refs. 4,7 \\
$\mathrm{YBa}_{2} \mathrm{Cu}_{4} \mathrm{O}_{8}$ & -340269.7 & 101.7523 & 1.9506 & refs. 7,11 \\
\hline$\Delta_{f} G^{\circ} / R=\mathrm{A}+\mathrm{B} T+\mathrm{C} T(1-\ln T), \Delta_{f} H^{\circ} / R=\mathrm{A}+\mathrm{C} T, \Delta_{f} S^{\circ} / R=\mathrm{Cln} T-\mathrm{B}, \Delta c_{p}^{\circ} / R=\mathrm{C}$.
\end{tabular}

\section{EQUILIBRIA AND STABILITY}

The final goal of the thermodynamic investigation is not the thermodynamic data but the understanding of the behavior of a substance under various conditions. First, such understanding appears because of the calculation of equilibria for various chemical reactions and phase transitions. With the help of these data phase equilibria in the $\mathrm{Y}-\mathrm{Ba}-\mathrm{Cu}-\mathrm{O}$ system were calculated. Some phase boundaries calculated by a constrained free energy minimization are shown in Fig. 3. As can be seen, there is a variety of phase fields, most of them have not been detected experimentally yet. This is due, on the one hand, to lack of sufficient experiments, and on the other, to the occurrence of metastable equilibria, which often exist in practice inhibiting the recognition of the true thermodynamically stable phase composition.

The phase equilibria and the stability range of the 123 solid solution are plotted on temperature versus composition axes in Fig. 4. The thin solid lines in Fig. 4 represent temperature dependence of equilibrium composition at fixed oxygen pressure; short dashed lines represent the equilibria of the orthorhombic and tetragonal phases, while bold solid lines 1,2 , and 3 represent decomposition according to reactions:

$9 \mathrm{YBa}_{2} \mathrm{Cu}_{3} \mathrm{O}_{6+2}=\mathrm{YBa}_{4} \mathrm{Cu}_{3} \mathrm{O}_{8.5}+4 \mathrm{Y}_{2} \mathrm{BaCuO}_{5}+10 \mathrm{BaCu}_{2} \mathrm{O}_{2}+(5.5+9 \mathrm{z}) / 2 \mathrm{O}_{2}$, $6 \mathrm{YBa}_{2} \mathrm{Cu}_{3} \mathrm{O}_{6+z}=2 \mathrm{Y}_{2} \mathrm{Ba}_{4} \mathrm{Cu}_{7} \mathrm{O}_{14+z}+\mathrm{Y}_{2} \mathrm{BaCuO}_{5}+3 \mathrm{BaCuO}_{2}+(4 \mathrm{z}-3) / 2 \mathrm{O}_{2}$, and $6 \mathrm{YBa}_{2} \mathrm{Cu}_{3} \mathrm{O}_{6+\mathrm{z}}=\mathrm{Y}_{2} \mathrm{Ba}_{4} \mathrm{Cu}_{7} \mathrm{O}_{14+\mathrm{z}}+2 \mathrm{Y}_{2} \mathrm{BaCuO}_{5}+3 \mathrm{Ba}_{2} \mathrm{Cu}_{3} \mathrm{O}_{5+\mathrm{y}}+(5 \mathrm{z}-3 \mathrm{y}-3) / 2 \mathrm{O}_{2}$ respectively. 

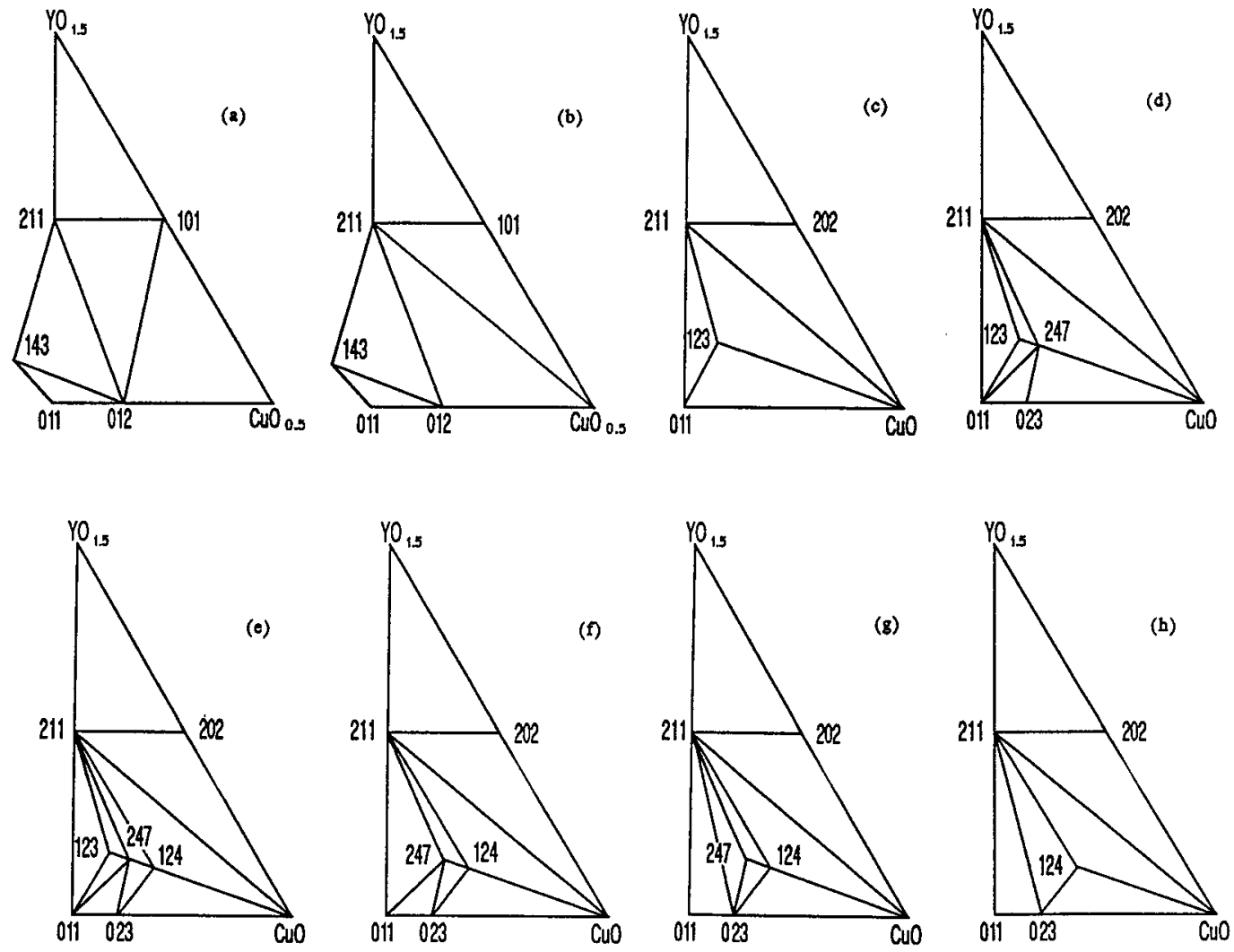

Fig. 3. Phase relationships for the $\mathrm{YO}_{1.5}-\mathrm{BaO}-\mathrm{CuO} / \mathrm{Cu}_{2} \mathrm{O}$ system at $1100 \mathrm{~K}$ and the following oxygen pressures: $10^{-5}$ (a), $10^{-4}$ (b), 0.2 (c), 1 (d), 2 (e), 5 (f), 10 (g) and $15 \mathrm{~atm}(\mathrm{~h})$. The phases are denoted as follows: $\mathrm{Y}_{2} \mathrm{Cu}_{2} \mathrm{O}_{5}(202), \mathrm{YCuO}_{2}$ (101), $\mathrm{BaCuO}_{2}$ (011), $\mathrm{BaCu}_{2} \mathrm{O}_{2}$ (012), $\mathrm{Ba}_{2} \mathrm{Cu}_{3} \mathrm{O}_{5+\mathrm{y}}$ (023), $\mathrm{Y}_{2} \mathrm{BaCuO}_{5}$ (211), $\mathrm{YBa}_{4} \mathrm{Cu}_{3} \mathrm{O}_{8.5}$ (143), $\mathrm{YBa}_{2} \mathrm{Cu}_{3} \mathrm{O}_{6+z}$ (123), $\mathrm{Y}_{2} \mathrm{Ba}_{4} \mathrm{Cu}_{7} \mathrm{O}_{14+\mathrm{z}}$ (247) and $\mathrm{YBa}_{2} \mathrm{Cu}_{4} \mathrm{O}_{8}$ (124).

The 123 phase is thermodynamically stable only in the cross-hatched field limited by the bold lines, which correspond to the equilibria of 4 solid phases and an oxygen gas. At temperature and composition outside this field, 123 is thermodynamically unstable with respect to decomposition into the other substances according to the reactions mentioned above. When the nucleation and/or growth of phases with cation stoichiometry other than 1:2:3 is kinetically suppressed, the 123 phase can exist for a long time as a metastable phase. In such a case, the metastable equilibria between the orthorhombic and tetragonal phases represented by the short dashed lines in Fig. 4 take place.

The stability diagrams of the superconducting phases that have been synthesized in the $\mathrm{Y}-\mathrm{Ba}-\mathrm{Cu}-\mathrm{O}$ system are superimposed in Fig. 5, where bold solid lines represent the decomposition of the 123 phase according to reactions 1,2 and 3 mentioned in Fig. 4, while thin solids lines 4 and 5 represent decomposition of the 247 phase according to the reactions: $5 \mathrm{Y}_{2} \mathrm{Ba}_{4} \mathrm{Cu}_{7} \mathrm{O}_{14+\mathrm{z}}=6 \mathrm{YBa}_{2} \mathrm{Cu}_{4} \mathrm{O}_{8}+2 \mathrm{Y}_{2} \mathrm{BaCuO}_{5}+3 \mathrm{Ba}_{2} \mathrm{Cu}_{3} \mathrm{O}_{5+\mathrm{y}}+(5 \mathrm{z}-3 \mathrm{y}-3) / 2 \mathrm{O}_{2}$, and $\mathrm{Y}_{2} \mathrm{Ba}_{4} \mathrm{Cu}_{7} \mathrm{O}_{14+\mathrm{z}}=2 \mathrm{YBa}_{2} \mathrm{Cu}_{3} \mathrm{O}_{6+z}+\mathrm{CuO}+(1-\mathrm{z}) / 2 \mathrm{O}_{2}$ respectively. Long dashed line 6 in Fig. 5 represents decomposition of the 124 according to the reaction $2 \mathrm{YBa}_{2} \mathrm{Cu}_{4} \mathrm{O}_{8}=\mathrm{CuO}+$ $\mathrm{Y}_{2} \mathrm{Ba}_{4} \mathrm{Cu}_{7} \mathrm{O}_{14+\mathrm{z}}+(1-\mathrm{z}) / 2 \mathrm{O}_{2}$. There are also arrows showing the stability range of each phase. The equilibrium between 123 and 124 associated with the reaction $\mathrm{YBa}_{2} \mathrm{Cu}_{4} \mathrm{O}_{8}=$ $\mathrm{YBa}_{2} \mathrm{Cu}_{3} \mathrm{O}_{6+2}+\mathrm{CuO}+(1-\mathrm{z}) / 2 \mathrm{O}_{2}$ is a metastable one, therefore, it is not shown in Fig. 5. 


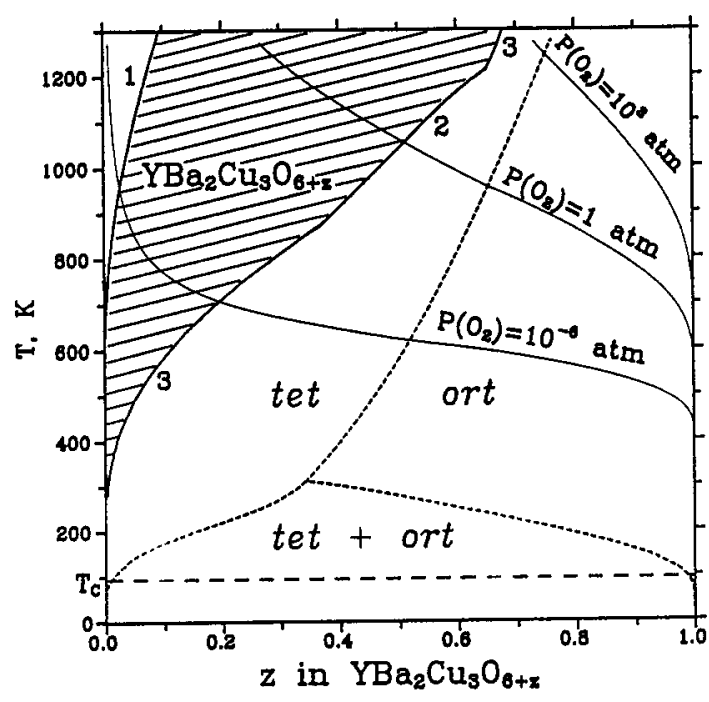

Fig. 4. Stability field of the 123 phase in the $\mathrm{Y}-\mathrm{Ba}-\mathrm{Cu}-\mathrm{O}$ system.

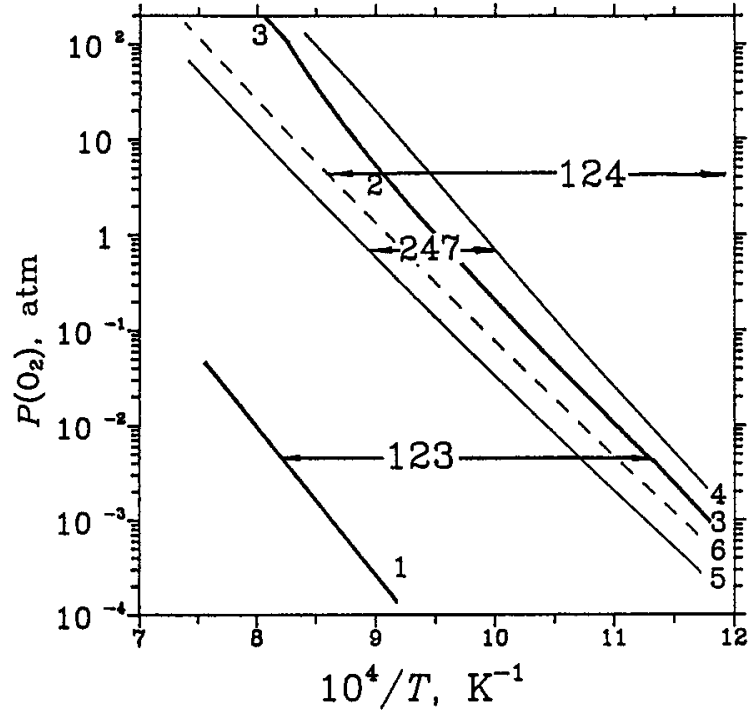

Fig. 5. Stability fields of the superconducting phases in the $\mathrm{Y}-\mathrm{Ba}-\mathrm{Cu}-\mathrm{O}$ system.

Decomposition of the 124 phase according to the reaction $4 \mathrm{YBa}_{2} \mathrm{Cu}_{4} \mathrm{O}_{8}=2 \mathrm{Y}_{2} \mathrm{BaCuO}_{5}+5 \mathrm{CuO}+$ $3 \mathrm{Ba}_{2} \mathrm{Cu}_{3} \mathrm{O}_{5+y}+(2-3 \mathrm{y}) / 2 \mathrm{O}_{2}$ occurs at temperatures too low to be shown in Fig. 5 . For instance, this equilibrium is established at $536 \mathrm{~K}$ and 1 atm of oxygen pressure. It is important that not only the 123 and 247 superconductors but also 124 loses its thermodynamic stability upon cooling. Phase boundaries corresponding to different decomposition reactions are often close to one another. Owing to the experimental uncertainties in the values of the thermodynamic properties of the phases used for the calculations, it is sometimes hard to suggest which of these boundaries is stable and which is metastable, although, as a rule, the location and dimensions of the stability field remain practically unchanged.

\section{DISCUSSION}

The problem of the thermodynamic stability of any new material is important and attractive. Especially it, can be attributed to the stability of the superconductors, since in the theory of superconductivity, the idea exists that any superconductor is a thermodynamically unstable system (ref. 24). This conclusion had been made well before the discovery of modern HTSC. It was based on the well-known theory of the superconductivity developed by Bardeen, Cooper, and Schrieffer, and on its generalization. According to this theory, the superconducting transition temperature depends on the Debye temperature of a crystal $(\theta)$ according to the expression

$$
T_{c} \approx 0.25 \theta \exp (-1 / \lambda)
$$

where the parameter $\lambda$ also depends on $\theta$, decreasing rapidly (approximately as the square of $\theta$ ) with increase of the characteristic frequency of a crystal lattice. Therefore, the high values of $T_{c}$ were attributed to low frequencies in the crystal lattice vibrational spectrum. From the point of view of thermodynamics, this means the loss of the stability for the phase of interest with respect to the other virtual states of the substance. It was supposed that the superconductors with high $T_{c}$ had a tendency to transform into the crystal with lower symmetry. In fact, they deal only with mechanical and thermal stability of a crystal. But, as we know, the main problem is its chemical stability, that is the stability with regard to chemical reactions and decomposition on the new phases. 
It is the chemical opinion on the stability of the new superconductors (ref. 25). In this approach they are regarded as mixed valent compounds. For example, they have copper in three different valency states. The tendency to disproportionate copper with valency +2 into two states with valency +1 and +3 can lead to superconductivity and, simultaneously, to decomposition of the primary superconducting phase into two nonsuperconducting phases. Evidently, these conclusions about the absence of thermodynamic stability cannot be regarded as rigorous. They look like the interesting hypotheses but not as rigorous approaches to this problem. This question can only be solved with the help of direct thermodynamic investigations.

As far as practice is concerned, materials in different states of thermodynamic equilibrium exist and moreover, they are used. For example, most semiconductor devices such as transistors or multi-layer structures are in thermodynamically unstable, labile states. Of course, at low rates of relaxation, a system can exist in a such state for a very long time, but, in principle, this time is limited. On the contrary, metastable equilibrium can exist for any time, since there is a local minimum of its thermodynamic potential with respect to the internal thermodynamic variables. In fact, this minimum can be deep enough, so that the difference between metastable and stable equilibria can hardly be distinguished. A diamond is an example of a metastable state. On the other hand, a metastable state is close to unstable one if this minimum is flat. That is to say the 'verdict' passed on the thermodynamics of unstable material has, as is known in the light of various kinetic prohibitions, no definite time of application, but the duration of its effect is eternity, and this must be taken into account in selecting the conditions for use of articles of such material. It is worth noting, that the thermodynamics alone cannot predict whether the thermodynamically unstable or metastable material actually decomposes or not. Yet, if a material of interest is stable, then thermodynamics will guarantee that process of decomposition cannot occur under any circumstances. It is possible to describe the stability of equilibria quantitatively, but this requires a lot of additional thermodynamic data.

As it was shown previously, direct thermodynamic investigation of stability was performed for the superconductors in the $\mathrm{Y}-\mathrm{Ba}-\mathrm{Cu}-\mathrm{O}$ system. The superconducting orthorhombic 123 phase is thermodynamically unstable at any temperature and composition (see Fig. 4). That is why a two-stage method is generally used to obtain it in a metastable state. At first, the tetragonal phase is synthesized at 900 to $960^{\circ} \mathrm{C}$ and at the oxygen pressure of 0.2 to $1 \mathrm{~atm}$, which corresponds to the region of its stability, shown in Fig. 5. Then, the preparation of the superconducting orthorhombic structure and its annealing to increase the oxygen content are carried out under 1 atm of oxygen pressure at lower temperatures according to the metastable equilibria of the orthorhombic and tetragonal phases (see the short dashed lines and 1 atm isobar in Fig. 4). It is worth noting that the 123 phase cannot decompose into $\mathrm{Y}_{2} \mathrm{BaCuO}_{5}, \mathrm{BaCuO}_{2}$, $\mathrm{CuO}$ and oxygen, although this way seems the most direct one. The thermodynamic calculations show that all the other superconductors in this system also can exist only in metastable states under application conditions, i.e., at low temperature and moderate oxygen pressure.

The stability ranges of the 123, 124 and 247 superconductors shown in Fig. 5 may somewhat decrease because of decomposition into the other phases from this family, such as 125, if these phases appear to be stable. The same may be due to the formation of $\mathrm{BaO}_{2}$ at low temperatures and high pressures, since barium peroxide was not taken into account in the above calculations of equilibria. This was confirmed by investigation of phase equilibria in the $\mathrm{Y}-\mathrm{Ba}-\mathrm{Cu}-\mathrm{O}$ system at high pressure of oxygen (ref. 26). If the thermodynamic properties of barium peroxide from the existing compilations are used for the calculation, then it will turn out that not only the superconducting phases but also many their decomposition products must be oxidized even by ambient air because of the formation of barium peroxide. Unfortunately, the thermodynamic properties of barium peroxide are not well enough defined to draw a definite conclusion. This can be said about the properties of many other substances of interest. In due course, this lack of precise data will be corrected, but only after extensive work in this field.

The question of the thermodynamic stability of the superconductors in the $\mathrm{Bi}-\mathrm{Sr}-\mathrm{Ca}-\mathrm{Cu}-$ $\mathrm{O}$, Ti-Ba-Ca-Cu-O and other multicomponent systems is far from being settled. The necessary for the calculation of equilibria thermodynamic functions such complex systems are not established now, and one cannot hope, that we be able to do this in a year or two. 


\section{CONCLUSIONS}

The main problems in the thermodynamics of the new superconductors are connected with their stability. The calculation of equilibria between the substance of interest and other phases can help to find the external conditions for its stability. Owing to the lack of necessary thermodynamic data, such equilibria have only be calculated for superconductors in the $\mathrm{Y}-\mathrm{Ba}-\mathrm{Cu}-\mathrm{O}$ system. It is shown that the superconducting orthorhombic 123 phase is thermodynamically unstable at all temperatures and compositions. It may exist for a long time as a metastable phase when the nucleation of the other phases with cation stoichiometry other than 1:2:3 is kinetically suppressed. The 247 and 124 superconductors are also metastable under application conditions if we consider the possibility of formation of the other phases in this system. With regard to thermodynamic investigations, the other systems with high-temperature superconductors are much more complicated. Neither their thermodynamic properties nor phase compositions have been studied yet.

\section{REFERENCES}

1. K.S. Gavrichev, V.E. Gorbunov, I.A. Konovalova, V.B. Lazarev, E.A. Tishchenko and I.S. Shaplygin, Izv. AN SSSR, Neorg. Mater. 24, 343-345 (1988).

2. A. Junod, D. Eckert, T. Graf, E. Kaldis, J. Karpinski, S. Rusiecki, D. Sanches, G. Triscone and J. Muller, Physica C 168, 47-56 (1990).

3. R. Shaviv, E.F. Westrum, R.J.C. Born, M. Sayer, X. Yu and R.D. Weir, J. Chem. Phys. 92, 6794-6799 (1990).

4. B.T. Ahn, V.Y. Lee, R. Beyers, T.M. Gur and R.A. Huggins, Physica C 167, 529-537 (1990).

5. K. Borowiec and K. Kolbrecka, Jap. J. Appl. Phys. 28, L1963-L1966 (1989).

6. T.B. Lindemer, J.F.Hunley, J.E. Gates, A.L. Sullon, Jr. J. Brynestad, C.R. Hubbard and P.K. Gallagher, J.Am. Ceram.Soc. 72, 1175-1188 (1989).

7. G.F.Voronin and S.A.Degterov, Physica C 176, 387-408 (1991).

8. Yu.Ya. Skolis, S.F. Pashin and M.L. Kovba, Superconductivity: Phys. Chem. Eng. 3, 2792-2797 (1990).

9. S.F. Pashin and Yu.Ya. Skolis, Zhur. Fiz. Khim. 65, 256-259 (1991).

10. S.F. Pashin, E.V. Antipov, L.M. Kovba and Yu.Ya. Skolis, Superconductivity: Phys. Chem. Eng. 2, 102-107 (1989).

11. G.F. Voronin, S.A. Degterov and Yu.Ya. Skolis, Proc. 3rd German-Soviet Bilateral Seminar on High-Temperature Superconductivity, October 8-12, 1990, Karlsruhe, Germany, p. 562-568.

12. Fan Zhanguo, Ji Chunlin and Zhao Zhongxian, J. Less-Common Metals 161, 49-59 (1990).

13. L.R.Morss, S.E.Dorris, T.B.Lindemer and N.Naito, Eur.J. Solid State Inorg. Chem. 27, 327-332 (1990).

14. A.S. Monaenkova, A.A. Popova, N.V. Zajtzeva, M.A. Bikov and S.L. Jaguzhinskij, Superconductivity: Phys. Chem. Eng. 3, 955-962 (1990).

15. Yu.Ya. Skolis, M.L. Kovba and L.A. Chramzova, Zhur. Fiz. Khim. 65 (in press).

16. D.Sh. Zagareshvily, G.G. Gvelesiany, I.B. Baratashvily, Zhur. Fiz. Khim. 64, 2606-2610 (1990).

17. V.E. Gorbunov, K.S. Gavrichev, G.A. Sharpataya, I.S. Shaplygin and V.I. Zalukaev, Russ. J. Inorg. Chem. 26, 547 (1981).

18. S.A. Degterov, Superconductivity: Phys. Chem. Eng. 3, 115-124 (1990).

19. J.C.Thompson, J.D.F. Gerald, R.L. Withers, P.J. Barlow and J.S. Anderson, Mat. Res. Bull 24, 505-515 (1989).

20. JANAF Thermochemical Tables, 1975,1982 Supplements.

21. Thermodynamic Properties of Individual Substances: Reference Book, vol. 4, Nauka, Moscow (1982).

22. E.G. Lavut and N.V. Chelovskaja, J. Chem. Thermod. 22, 817-820 (1990).

23. S.N. Mudretsova, I.A. Vasiljeva and Zh.V. Filippova, Zhur. Fiz. Khim. 63, 3108-3111 (1989).

24. W.L. Johnson, in Physical Metallurgy (R.W. Cahn and P. Haasen eds.), North-Holland Physics Publ., Amsterdam (1983).

25. A.W. Sleight, Chemtronics 2, 116-119 (1987).

26. M.R. Chandrachood, D.E. Morris and A.P.B. Sinha, Physica C 171, 187-193 (1990). 